\title{
Pancreatic cyst in a cat
}

\section{Ellen Bethânia de Oliveira Cavalcanti ${ }^{1}$ Alana Carmela Ferrareis Cerqueira ${ }^{2}$ Beatriz Barbosa Kaiser $^{2}$ Thieissa Moraes Venturotti ${ }^{2}$ Cynthia Brandão da Costa ${ }^{1}$ Rodrigo dos Santos Horta ${ }^{3}$ Fabiana Michelsen de Andrade ${ }^{4}$ (iD) Clairton Marcolongo-Pereira ${ }^{2^{*}}$}

\footnotetext{
${ }^{1}$ Médico Veterinário Autônomo, Vitória, ES, Brasil.

${ }^{2}$ Faculdade de Medicina Veterinária, Centro Universitário do Espírito Santo (UNESC), 29703-858, Colatina, ES, Brasil. E-mail: clairton.marcolongo@terra.com.br. "Corresponding author.

${ }^{3}$ Departamento de Clínica e Cirurgia Veterinárias, Universidade Federal de Minas Gerais (UFMG), Belo Horizonte, MG, Brasil.

${ }^{4}$ Departamento de Zootecnia, Faculdade de Agronomia, Universidade Federal do Rio Grande do Sul (UFRGS), Porto Alegre, RS, Brasil.
}

\begin{abstract}
Pancreatic cysts are rare in both humans and animals. They are defined as an enclosed structure externally surrounded by a capsule, internally coated with a cuboidal epithelium and filled with liquid or semi-solid content. This case described the clinical and pathological characteristics of a pancreatic cyst in a feline. A mixed breed cat with a history of recurrent vomiting was attended. Physical examination revealed pain on abdominal palpation. Abdominal ultrasonography showed a cystic, anechoic structure with well-defined edges located in the left cranial abdomen and in close contact with the duodenum and pancreas. Partial pancreatectomy was performed. Microscopically, the structure was surrounded by fibrous material, coated with cuboidal to columnar epithelium, and containing eosinophilic material. Although, pancreatic cyst is rare in animals, they should be included in the differential diagnosis of causes of vomiting in young cats. Key words: feline, pancreas, cystic, duct dilatation.
\end{abstract}

Cisto pancreático em um gato

RESUMO: Os cistos epiteliais pancreáticos são raros em humanos e animais, e são definidos como estruturas encapsuladas rodeadas por epitélio cuboidal, preenchido por substância líquida. O objetivo desse estudo foi descrever as características clínico-patológicas de um cisto pancreático verdadeiro em um felino. Foi atendido uma gata sem raça definida com histórico de vômitos recorrentes. No exame físico o animal apresentou dor à palpação abdominal. Na ultrassonografia abdominal, evidenciou-se a presença de uma estrutura cística, anecóica e com bordos bem definidos localizado no abdome cranial esquerdo, em contato com o duodeno e o pâncreas. Foi realizada pancreatectomia parcial. No exame microscópico observou-se estrutura encapsulada, circundado por material fibroso, revestido por epitélio cuboidal a colunar, contendo material eosinofilico. Embora os cistos pancréticos verdadeiros sejam raros nos animais, eles devem ser incluídos no diagnóstico diferencial de doenças que cursam com vômitos nos gatos.

Palavras-chave: felinos, pâncreas, cistos, dilatação de ductos.

Cysts are defined as an enclosed structure externally surrounded by a capsule, internally coated with a cuboidal epithelium and filled with liquid or semi-solid content (BODEN \& ANDREWS, 2017). Pancreatic cysts or true pancreatic cysts are rare in animals and humans (HINES et al., 1996; SMITH et al., 1998; VANEKVORT et al., 1999; COLEMAN et al., 2005; KHAN et al., 2011), and may occur due to benign, mainly malformation, but also malignant processes (KHAN et al., 2011).

Pancreatic pseudocysts are characterized by inflammatory fluid collections and the cystic lesion has no epithelial lining. Pseudocysts, mainly associated with chronic pancreatitis, and mucincontaining neoplastic lesions such as cystadenomas and cystadenocarcinomas are still rare in animals but are amidst the most common cystic structures observed in the human pancreas (KHAN et al., 2011; BRUGGE 2015).

Cystic lesions can remain asymptomatic or the patient can develop unspecific clinical signs, including vomiting, weight loss and hyporexia. Occasionally cyst rupture can result in peritonitis and severe clinical signs as abdominal pain, dehydration, 
icterus and hypotension related to vasogenic shock (COLEMAN et. al 2005; BRANTER et al. 2010). Cysts must be differentiated from pseudocysts, once pathogenesis is largely distinct (KHAN et al., 2011; BRUGGE 2015). Nevertheless, surgery might be indicated for treatment and subsequent histopathological diagnosis (COLEMAN et. al 2005; BRANTER et al. 2010).

This e report described the clinical and pathological characteristics of a pancreatic cyst in a mixed-breed cat emphasizing the efficiency of the surgical approach.

An 11-month-old entire female cat weighing $2.6 \mathrm{~kg}$ was treated for recurrent vomiting. She had no outdoor access; all her vaccines were upto-date, and she was negative for both retroviruses on SNAP combo for Feline immunodeficiency virus/ Feline leukemia virus (FIV/FeLV). On physical examination, the patient presented pain on abdominal palpation, with the presence of a floating mass of soft consistency in the epigastric region. Blood cell count and serum biochemistry results were within normal reference range. Abdominal ultrasound revealed the presence of a cystic, anechoic structure, measuring approximately $2.53 \times 3.40 \mathrm{~cm}$ with well-defined edges and measuring approximately $0.29 \mathrm{~cm}$ thick
(Figure 1) with close contact with the duodenum and pancreas. An exploratory laparotomy was performed showing a cystic structure of approximately $3 \mathrm{~cm}$ in diameter located in the pancreas (Figure 2). The structure was completely removed together with a portion of the serosa of the duodenum and submitted for histological analysis, where it was fixed in $10 \%$ buffered formalin, processed routinely, cut in $3 \mu \mathrm{m}$ sections and stained with hematoxylin and eosin.

Grossly, the structure had $3 \mathrm{~cm}$ in diameter and was cystic, rough, soft, and with well-defined limits. The cyst contents were opaque, brown, and liquid. Histopathological examination of the pancreas revealed cystic structures, surrounded by mild to moderate fibrous tissue, lined with cuboidal to columnar epithelium, and filled with eosinophilic material (Figure 3A and 3B). No communication of the cyst with the pancreatic duct or further changes was observed.

The cat was followed for 24 months after the surgical procedure. No recurrent clinical signs or abnormalities on serial ultrasound examinations were observed.

EDTA blood sample was tested for C3284A mutation in exon 29 of the PKD1 gene, and no mutation was observed, presenting a normal result

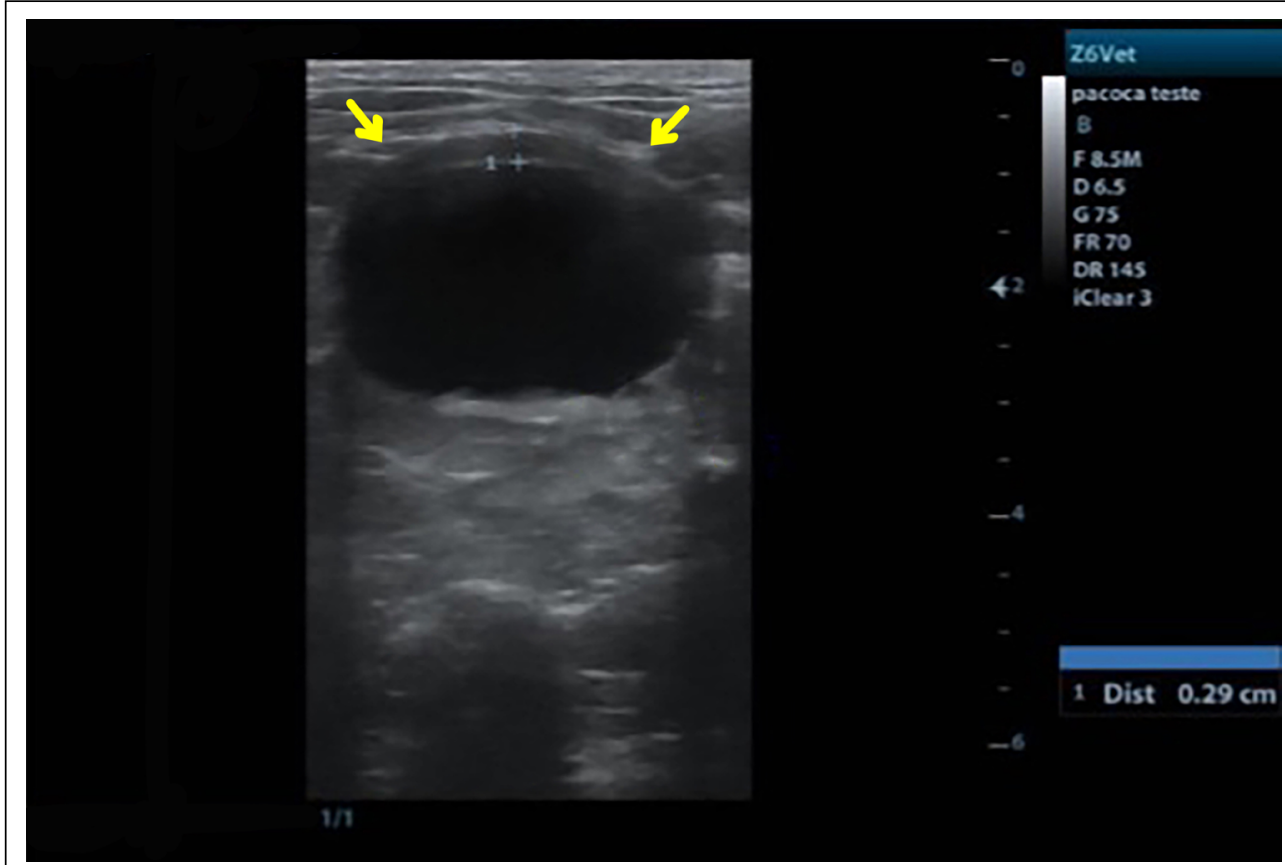

Figure 1- Cat - Abdominal ultrasound showing an anechoic cystic structure (arrows) in close contact with the pancreas and duodenum, measuring approximately $2.53 \times 3.40 \mathrm{~cm}$ with well-defined edges and measuring approximately $0.29 \mathrm{~cm}$ thick. 


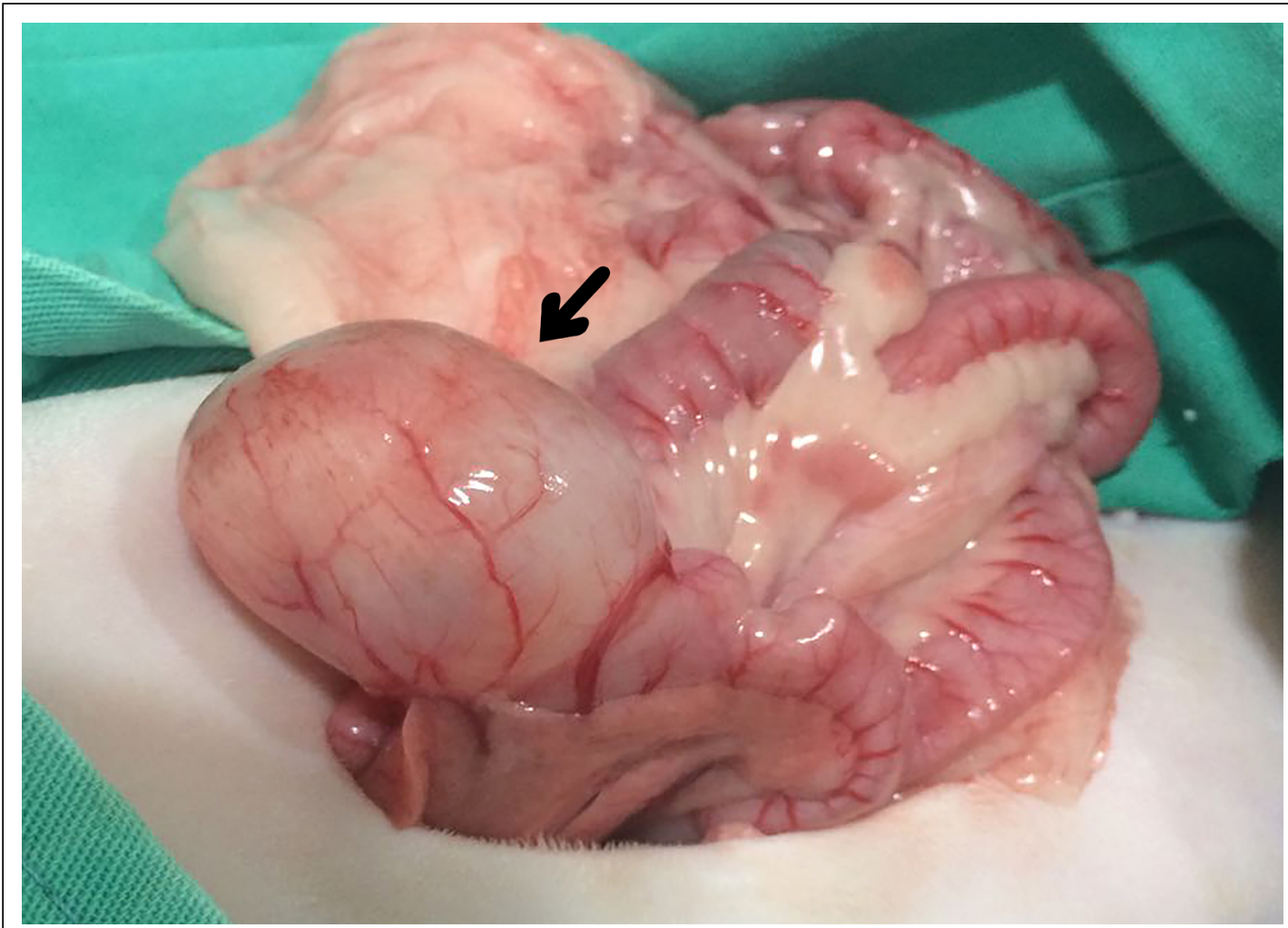

Figure 2 - Cat - A cystic structure (arrow) of approximately $3 \mathrm{~cm}$ in diameter connected to the central body of the pancreas.

(homozygous for the $\mathrm{C}$ allele). The genotyping was performed through PCR, using primers and conditions described by LEE et al. (2010). The PCR product of $321 \mathrm{pb}$ was digested by a restriction enzyme reaction with $M s p$ I for allele discrimination, together with a heterozygous sample, used as positive control for the restriction reaction. The products were visualized in $2 \%$ agarose gel, after electrophoresis using a $100 \mathrm{pb}$ ladder.

The diagnosis of a pancreatic cyst in this cat was based on imaging findings, macroscopy and histopathological examination of the cyst, which was coated with a layer of cuboidal epithelium and had no communication with the pancreatic duct (BERGIN et al., 2002). In this case, the cyst probably occurred due to an anomalous malformation of one of the pancreatic ducts, which is the usual cause of these cysts in humans (BERGIN et al., 2002).

Pancreatic cysts can also be associated with genetic diseases such as polycystic kidney disease, von Hippel-Lindau disease, and cystic fibrosis, which generally promote concomitant lesions in other organs (BERGIN et al., 2002). Feline polycystic kidney disease can lead to the formation of cysts in the kidneys, but also in the liver and pancreas (BOSJE et al., 1998). The feline in this case report was negative for C3284A mutation in exon 29 of the PKD1 gene.

Vomiting was the main clinical sign observed in this case and; although nonspecific, it seemed to be the main clinical sign associated with the presence of pancreatic cysts or pseudocysts in cats (BRANTER et al., 2010; COLEMAN et al., 2005; HINES et al., 1996; VANENKEVORT et al., 1999; BRÜCKNER 2019). Vomiting often occurs due to obstruction of the bile duct (COLEMAN et al., 2005 ) or due to local inflammation, which stimulates the vagus nerve (BABIC \& BROWNING 2014). Interestingly, none of these changes were found in this case. However, the episodes of vomiting and poor appetite disappeared immediately after surgery which would support our diagnosis as the cause of the clinical signs.

Abdominal ultrasonography and computed tomography (CT) are generally useful as auxiliary methods in the diagnosis and definition of pancreatic

Ciência Rural, v.51, n.11, 2021. 


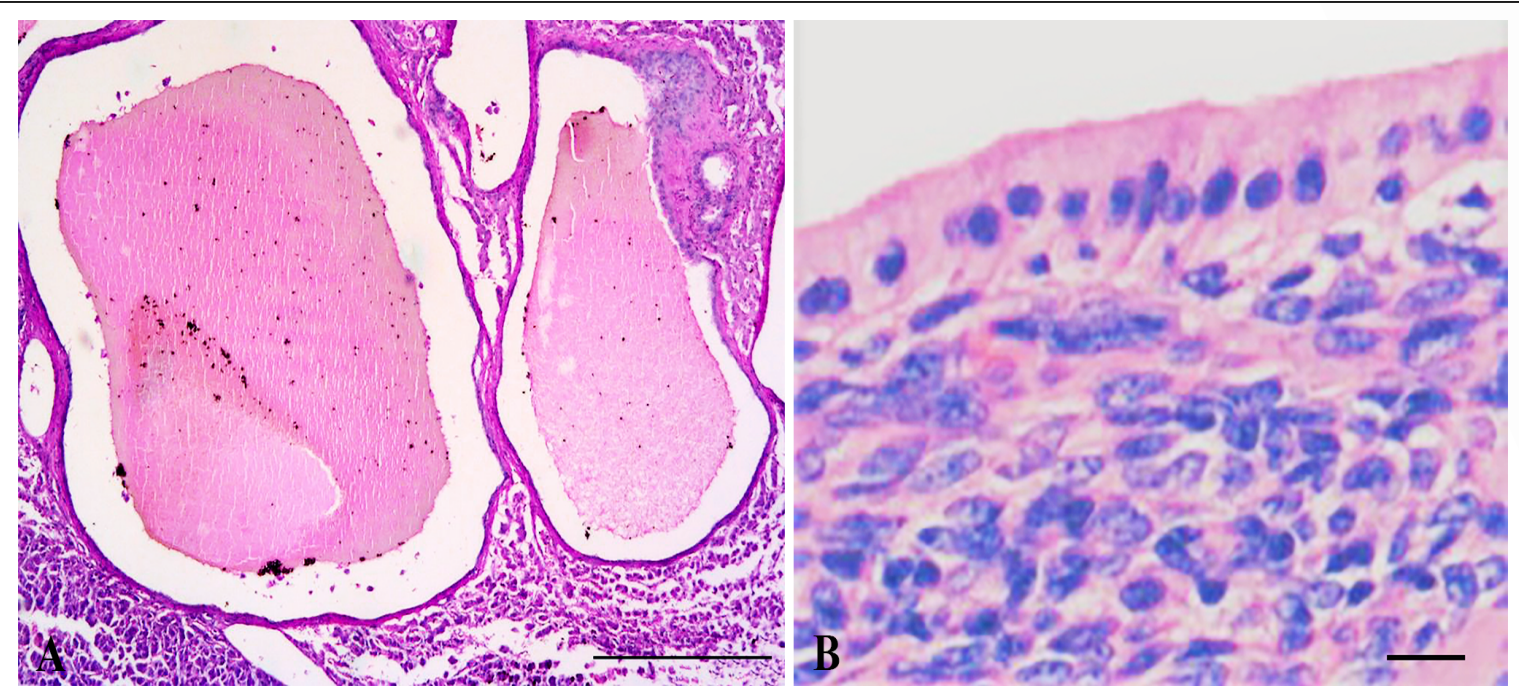

Figure 3 - Cat -A) Pancreas: Irregularly contoured cysts containing amorphous eosinophilic material (HE, Bar $200 \mu \mathrm{m})$. B) Cuboidal to columnar epithelium coating the entire cyst surrounded by mild to moderate amount of fibrous tissue (HE, Bar $50 \mu \mathrm{m})$.

cysts (BRANTER et al., 2010; COLEMAN et al., 2005; HINES et al., 1996; VANENKEVORT et al., 1999; BRÜNCKER, 2019). However, CT was not performed in the present case. Additionally, ultrasound-guided fine needle aspiration can aid in collecting fluid for cytological examination, bacterial culture, and detection of amylase or pancreatic lipase activity, favoring the diagnosis of the lesion (SMITH et al., 1998). The definitive diagnosis can also be performed by exploratory surgery. Surgery may also have a therapeutic effect as well as preventing a possible peritonitis caused by cyst rupture (BRÜNCKER, 2019).

Cystic lesions of the pancreas are more common in humans than in animals and only few cases of pancreatic cyst in cats were described. Pancreatic cyst should be included in the differential diagnosis of causes of vomiting in young cats with or without anorexia. Clinicians should have a systematic approach for establishing a diagnosis, but exploratory surgery can be performed in an attempt for concomitant diagnosis and treatment.

\section{ACKNOWLEDGEMENTS}

This work was supported by Fundação de Amparo à Pesquisa e Inovação do Espírito Santo - FAPES and was financed in part by the Coordenação de Aperfeiçoamento de Pessoal de Nível Superior (CAPES), Brasil - Finance code 001.

\section{BIOETHICS AND BIOSSECURITY COMMITTEE APPROVAL}

The authors of this article declared, for all due purposes, the project that gave rise to the present data of the same has not been submitted for evaluation to the Ethics Committee of the University / Research Institute "Centro Universitário do Espírito Santo - UNESC", but we are aware of the content of the Brazilian resolutions of the National Council for Control of Animal Experimentation - CONCEA "http://www.mct.gov.br/index.php/content/view/310553.html" if it involves animals. This is a case report of a sick cat that was brought to UNESC by the owner. Therefore, the diagnostic procedures were necessary and are part of the diagnostic routine. Thus, the authors assume full responsibility for the presented data and are available for possible questions, should they be required by the competent authorities.

\section{DECLARATION OF CONFLICT OF INTERESTS}

The authors declare no conflict of interest. The founding sponsors had no role in the design of the study; in the collection, analyses, or interpretation of data; in the writing of the manuscript, and in the decision to publish the results.

\section{AUTHORS' CONTRIBUTIONS}

All authors contributed equally for the conception and writing of the manuscript. All authors critically revised the manuscript and approved the final version.

\section{REFERENCES}

BABIC, T; BROWNING, K.N. The role of vagal neurocircuits in the regulation of nausea and vomiting. European Journal 
of Pharmacology, v.722, p.38-47, 2014. Available from: $<$ https://www.sciencedirect.com/science/article/abs/pii/ S0014299913007577?via\%3Dihub>. Acessed: Oct. 20, 2020. Doi: 10.1016/j.ejphar.2013.08.047.

BERGIN, D. et. al. Simple pancreatic cysts: CT and endoscopic appearances. American Journal of Roentgenology, v.178, n.4, p.837-40, 2002. Available from: <https://www.ajronline.org/doi/ full/10.2214/ajr.178.4.1780837>. Accessed: Jul. 15, 2020. Doi: 10.2214/ajr.178.4.1780837

BODEN, E.; ANDREWS, A. Black's Veterinary Dictionary. London: Bloomsburry, 2017. 984p.

BRANTER, E.M. et al. Multiple recurrent pancreatic cysts with associated pancreatic inflammation and atrophy in a cat. Journal of Feline Medicine and Surgery,v.12, n.10, p. 822-827, 2010 Available from: <https://journals.sagepub.com/doi/abs/10.1016/j. jfms.2010.06.005>. Accessed: Jul. 22, 2020. Doi:10.1016/j. jfms.2010.06.005.

BRUGGE, W.R. Diagnosis and management of cystic lesions of the pancreas. Journal of Gastrointestinal Oncology, v.6, n.4, p.375-388, 2015. Available from: <http://jgo.amegroups.com/ article/view/4497/4865>. Accessed: Sep. 02, 2020. doi: 10.3978/j. issn.2078-6891.2015.057.

BRÜNCKER, M. Laparoscopic omentalization of a pancreatic cyst in a cat. Journal of the American Veterinary Medical Association, v.255, n2, p. 213-218, 2019. Available from: $<$ https:// avmajournals.avma.org/doi/abs/10.2460/javma.255.2.213>. Accessed: Jul. 22, 2020. doi: <https://doi.org/10.1016/j. jfms.2010.06.005>.

BOSJE, J.T. et al. Polycystic kidney and liver disease in cats. Veterinary Quartely, v.20, n4, p.136-139, 1998. Available from: $<$ https://www.tandfonline.com/doi/pdf/10.1080/01652176.1998.9 694858>. Accessed: Aug. 31, 2020. doi: <https://doi.org/10.1080 /01652176.1998.9694858>
COLEMAN, M.G. et al. Pancreatic cyst in a cat. New Zealand Veterinary Journal,v.53, n2, p. 157-159, 2005. Available from: $<$ https:/www.tandfonline.com/doi/abs/10.1080/00480169.2005.3 6495>. Accessed: Jul. 18, 2020. doi: <https://doi.org/10.1080/00 480169.2005.36495>

HINES, B.L. et. al. Pancreatic pseudocyst associated with chronic-active necrotizing pancreatitis in a cat. Journal of the American Animal Hospital Association, v.53, n.2, p.147-152, 1996. Available from: <https://jaaha.org/doi/10.5326/1547331732-2-147?url ver=Z39.88-2003\&rfr id=ori:rid:crossref.org\&rfr dat $=$ cr_pub $\% \overline{2} 0 \% 200$ pubmed $>$. Accessed: Jul. 17, 2020. doi: $<$ https://doi.org/10.5326/15473317-32-2-147>.

KHAN, A. et al. Cystic lesions of the pancreas. American Journal of Roentgenology,v.196, n.6, p.668-677, 2011. Available from: $<$ https://www.ajronline.org/doi/abs/10.2214/AJR.10.4378>. Accessed: Jul. 15, 2020. doi: 10.2214/AJR.10.4378.

LEE, Y-J. et al. Diagnosis of feline polycystic kidney disease by a combination of ultrasonographic examination and PKD1 gene analysis. VeterinaryRecord, v. 167, n. 16, p.614-617, 2010. Available from: <https://veterinaryrecord.bmj.com/ content/167/16/614.long >. Accessed: Aug. 31, 2020. doi: <http:// dx.doi.org/10.1136/vr.c4605>

SMITH, S.A. et al. D.S. Resolution of a pancreatic pseudocyst in a dog following percutaneous ultrasonographic-guided drainage. Journal of the American Animal Hospital Association,v.34, n.6, p.515-522, 1998. Available from: <https://jaaha.org/doi/ abs/10.5326/15473317-34-6-515>. Accessed: Jul. 17, 2020. doi: $<$ https://doi.org/10.5326/15473317-34-6-515>.

VANEKVORT, B.A. et al. Pancreatic pseudocysts in 4 dogs and 2 cats: ultrasonographic and clinicopathologic findings Journal Veterinary Internal Medicine,v.13, n.4, p.309-313, 1999. Available from: <https://onlinelibrary.wiley.com/doi/ abs/10.1111/j.1939-1676.1999.tb02186.x>. Accessed: Jul. 22, 2020. doi: <https://doi.org/10.1111/j.1939-1676.1999.tb02186.x>. 